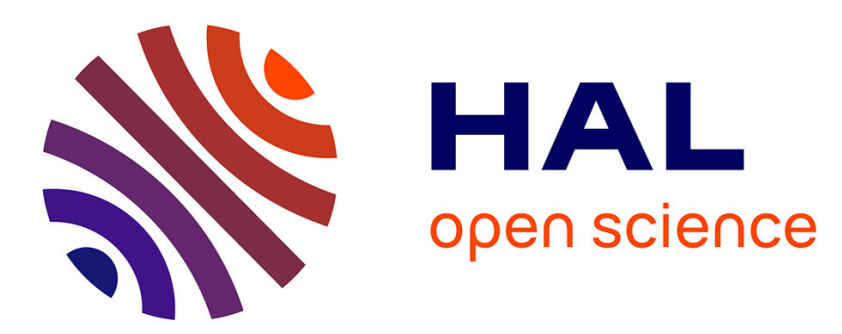

\title{
MYCOTOXIN DETECTION IN INFANT FORMULA MILKS IN ITALY
}

Valentina Meucci, Elisabetta Razzuoli, Giulio Soldani, Francesco Massart

\section{To cite this version:}

Valentina Meucci, Elisabetta Razzuoli, Giulio Soldani, Francesco Massart. MYCOTOXIN DETECTION IN INFANT FORMULA MILKS IN ITALY. Food Additives and Contaminants, 2009, 27 (01), pp.64-71. 10.1080/02652030903207201 . hal-00573904

\section{HAL Id: hal-00573904 https://hal.science/hal-00573904}

Submitted on 5 Mar 2011

HAL is a multi-disciplinary open access archive for the deposit and dissemination of scientific research documents, whether they are published or not. The documents may come from teaching and research institutions in France or abroad, or from public or private research centers.
L'archive ouverte pluridisciplinaire HAL, est destinée au dépôt et à la diffusion de documents scientifiques de niveau recherche, publiés ou non, émanant des établissements d'enseignement et de recherche français ou étrangers, des laboratoires publics ou privés. 


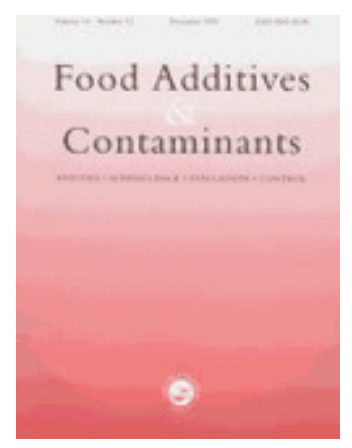

\section{MYCOTOXIN DETECTION IN INFANT FORMULA MILKS IN} ITALY

\begin{tabular}{|r|l|}
\hline Journal: & Food Additives and Contaminants \\
\hline Manuscript ID: & TFAC-2009-054.R1 \\
\hline Manuscript Type: & Original Research Paper \\
\hline Date Submitted by the & $17-J u l-2009$ \\
\hline Author: & $\begin{array}{r}\text { meucci, valentina; University of Pisa, Veterinary Clinics } \\
\text { razzuoli, elisabetta; University of Pisa, Veterinary Clinics } \\
\text { soldani, giulio; University of Pisa, Veterinary Clinics } \\
\text { massart, francesco; University of Pisa, Pediatrics }\end{array}$ \\
\hline Methods/Techniques: & Chromatography - HPLC, Clean-up - affinity columns \\
\hline Additives/Contaminants: & Mycotoxins, Mycotoxins - aflatoxins, Mycotoxins - ochratoxin A \\
\hline Food Types: & Baby food, Infant formulae, Milk \\
\hline
\end{tabular}

\section{SCHOLARONE $^{\text {m }}$ Manuscripts}


1

2

3

\section{MYCOTOXIN DETECTION IN INFANT FORMULA MILKS IN ITALY}

Valentina Meucci $^{\mathrm{a}^{*}}$, Elisabetta Razzuoli ${ }^{\mathrm{a}}$, Giulio Soldani ${ }^{\mathrm{a}}$, Francesco Massart ${ }^{\mathrm{b}}$.

Departments of ${ }^{\mathrm{a}}$ Veterinary Clinics, and ${ }^{\mathrm{b}}$ Pediatrics, University of Pisa, 56125 Pisa, Italy

*To whom correspondence should be addressed:

Valentina Meucci,

Department of Veterinary Clinics

Viale delle Piagge 2

56125 PISA

Italy

Tel.: (+39) 050-2216-803

Fax: (+39) 050-2216-813

E-mail: vmeucci@vet.unipi.it 


\begin{abstract}
After birth, infant formulas constitute an important or often sole food source for infants during the first months of life. In this study, a survey on the presence of aflatoxin $\mathrm{M}_{1}$ (AFM1) and ochratoxin A (OTA) in the 14 leading brands of infant formulas marketed in Italy was conducted. Mycotoxins were determined by immunoaffinity column clean-up and HPLC with fluorescence detection. AFM1 was found in 2 out of 185 samples but at levels below the European legislation limit of $25 \mathrm{ng} / \mathrm{L}$. OTA was detected in 133 (72\%) samples (range 35.1$689.5 \mathrm{ng} / \mathrm{L})$. It has been observed that OTA contamination was $80 \%$ in the ready-to-use preparations and $63 \%$ in the powdered samples. The Scientific Committee for Food (SCF) reviewed the toxicology on OTA and concluded that it would be prudent to reduce exposure to OTA ensuring that exposure is towards the lower end of the range of tolerable daily intakes of 1.2-14 ng/kg b.w. per day. OTA was also evaluated by the Joint FAO/WHO Expert Committee on Food Additives (JECFA) and a provisional tolerable weekly intake (PTWI) of $100 \mathrm{ng} / \mathrm{kg}$ b.w. was established. The OTA levels in pre-term ready-to-use infant formulas were sufficient to cause a higher OTA intake than the suggested TDI. Our results point out the need to perform controls for prevention programs especially when attempting to identify risk markers of the infant feed quality.
\end{abstract}

Key Words: ochratoxin A, aflatoxin M1, milk, infant formula, Italy, child health.

Word count of abstract: 224

Abbreviations. Aflatoxin M1 (AFM1); Aflatoxin B1 (AFB1); High Performance Liquid Chromatography (HPLC); Immunoaffinity Columns (IAC); Ochratoxin A (OTA); Tolerable Daily Intake (TDI). 


\section{INTRODUCTION}

Aflatoxins and ochratoxins are highly toxic secondary metabolites produced by several Aspergillus and Penicillium spp that can be found in different commodities including cow's milk. Aflatoxin M1 (AFM1), the major metabolite of aflatoxin B1 (AFB1), and ochratoxin A (OTA) are classified by the International Agency of Research on Cancer (IARC) as class 2B, possible human carcinogens (IARC, 1993a; 1993b). AFM1 level in milk and in milk products is regulated in several countries; the European Union (EU) limit of $0.05 \mu \mathrm{g} / \mathrm{kg}$ being one of the lowest in the world (EC, 2003a). In contrast, no regulation for OTA in milk exists, even though it has been suggested that OTA level in cow's milk may exceed the tolerable daily intake (TDI) of $5 \mathrm{ng} / \mathrm{kg}$ b.w. per day for small children in some areas in Norway (Skaug, 1999).

The Scientific Committee for Food (SCF) reviewed the toxicology on OTA and concluded in its opinion on OTA in food on the $17^{\text {th }}$ September 1998 (SCF, 1998) that there is an increasing concern about potential genotoxicity of OTA and its mechanism of action as a carcinogen. Therefore the Committee considered it would be prudent to reduce exposure to OTA as much as possible, ensuring that exposures are towards the lower end of the range of tolerable daily intakes of $1.2-14 \mathrm{ng} / \mathrm{kg}$ b.w. per day. OTA was also evaluated by the Joint FAO/WHO Expert Committee on Food Additives (JECFA) and a provisional tolerable weekly intake (PTWI) of $100 \mathrm{ng} / \mathrm{kg}$ b.w. was established (FAO/WHO, 2001). The European Food Safety Authority (EFSA) Scientific Panel on Contaminants in the Food Chain in considering all the toxicological and mechanistic data, established a Tolerable Weekly Intake (TWI) of $120 \mathrm{ng} / \mathrm{kg}$ body weight (EFSA, 2006).

Aflatoxins are predominantly produced in hot climates. In temperate countries, the strict control of imported feeds has limited the cases of milk contamination above the maximum tolerable limits. However, the presence of aflatoxins was recently reported in feeds 
grown in Europe (EC, 2003b; EFSA, 2004). The emergence of aflatoxins in the European continent is concurrent with the increase in the annual average temperature registered in the past decade (Anderson et al., 2004).

Investigations on milk AFM1 contamination are regularly conducted in European countries (EFSA, 2004), but there is little information on the milk contamination by other mycotoxins. In particular, there is scarce information on the presence of OTA in cow's milk (Skaug, 1999; Breitholtz-Emanuelsson et al., 1993; Valenta and Goll, 1996), and no data are available in Italy concerning infant milk-based formula contamination by this mycotoxin. Consumption of cow's milk has not previously been considered as possible source of OTA intake, because of the microflora in the rumen hydrolyses OTA to the less toxic metabolite ochratoxin $\alpha$ (Hult et al., 1976; Sreemannarayana et al., 1988). However, OTA has been found in bovine milk, in low concentrations, indicating that small amounts may escape rumen metabolism and are absorbed (Skaug, 1999; Breitholtz-Emanuelsson et al., 1993). The OTA concentration in cow's milk is expected to be very low, but even low concentrations might markedly increase OTA daily intake by consumers of large quantities of milk such as children, and contribute to significant portion of the total dietary intake (Skaug, 1999).

After birth, infant formulas constitute an important or often sole source of food for newborns and infants during the first months of life. Thus, these formulas have a special role in the infant diet because they should serve as substitutes for human milk. It is desirable that infant formulas should be proportionally similar or inferior in AFM1 and OTA levels to those found by human milk. In general, AFM1 and OTA concentrations in breast milk show marked variability depending on mother's life style and dietary habits. OTA was detected in milk from healthy mothers in Germany, Norway, Sweden, Hungary, Italy, Australia and Sierra Leone (Scott, 2005). Previous data from Italy had indicated a high prevalence of OTA in human milk samples with concentrations ranging between 1700-6600 ng/L and 100-12000 
ng/L, respectively (Micco et al., 1991; 1995). A second study has been carried out in Italy (Turconi et al., 2004). OTA was detected in 198 samples (85.7\%) at an average value of 6.01 ng/L. More recently, data from milk samples collected from 82 Italian women indicated that $74 \%$ of human milk samples contained OTA in the range $<5 \mathrm{ng} / \mathrm{L}-405 \mathrm{ng} / \mathrm{L}$ (Galvano et al., 2008). In the same study AFM1 was detected in four (5\%) of milk samples (ranging from $<7$ ng/L to $140 \mathrm{ng} / \mathrm{L}$ ) (Galvano et al., 2008). Relatively little work on the topic of mycotoxins in infant food has been reported in the literature (Galvano et al., 1998; 2001; Lombaert et al., 2003; Tam et al., 2006; Beretta et al., 2002). Most data have only been part of larger surveys of cereal foods (Lombaert et al., 2003; Tam et al., 2006; Beretta et al., 2002).

For these reasons, the aim of the following work was to determine AFM1 and OTA levels in the leading brands of infant formulas marketed in Italy, and then, to assess their repercussion in the provisional tolerable weekly intake of OTA and of AFM1. 


\section{METHODS}

\section{Samples}

From 14 commercial brands commonly marketed in Italy, a total of 185 samples (5 different batch numbers for each product) of infant formula powders $(\mathrm{n}=17)$ and ready-touse preparations $(n=20)$ were collected from 2006 to 2007 and analyzed. Cow's milk-based formulas were classified as pre-term formula ( $\mathrm{n}=11 ; 1$ powder and 10 liquid) and starter formula for infants from the first day to 6 months of age $(n=26,16$ powder and 10 liquid). Table 1 and 2 report their main characteristics.

\section{Standard preparation}

OTA (from Aspergillus ochraceus) (M 403.8) and AFM1 (from Aspergillus flavus) (M 328.2) reference standards, acetic acid (analytical reagent grade) and Celite were purchased from Sigma (Milan, Italy). The OTA standard was dissolved in a toluene-acetic acid mixture (99:1 $\%, \mathrm{v} / \mathrm{v}$ ) to give a stock solution of $200 \mu \mathrm{g} / \mathrm{ml}$ which was stored at $-20 \mathrm{C}$ until use. Working solutions were prepared by diluting the stock solution with the mobile phase consisting of methanol-sodium phosphate buffer ( $\mathrm{pH} 7.5)$ 45:55 v/v. The AFM1 standard was dissolved in a acetonitrile to give a stock solution of $10 \mu \mathrm{g} / \mathrm{ml}$ which was stored at $-20 \mathrm{C}$ until use. Working solutions were prepared by diluting the stock solution with the mobile phase consisting of acetonitrile-water 23:77 v/v. HPLC-grade water, methanol and acetonitrile were supplied by LABSCAN (Hasselt, Belgium). The immunOTAffinity columns (IAC) AflaStar® and OchraStar® were purchased from Tecna Srl (Trieste, Italy).

Mycotoxins are highly toxic substances, precautions must be observed when handling these substances, safety instructions for working with mycotoxins are given in Valenta (1998). All mycotoxins waste and contaminated laboratory materials were kept for $24 \mathrm{~h}$ in sodium hypochlorite solution (household bleach) for decontamination. 


\section{Samples preparation}

OTA. Five $\mathrm{ml}$ of infant formula samples were mixed with $15 \mathrm{ml}$ of extraction solution (water/methanol 50/50 v/v). Extraction was done by shaking for $5 \mathrm{~min}$ on horizontal shaker and centrifuging at $3000 \mathrm{rpm}$ for $10 \mathrm{~min}$. The extract $(4 \mathrm{ml})$ was diluted with $46 \mathrm{ml}$ of phosphate-buffered saline (PBS, $\mathrm{pH}$ 7.4). The diluted sample was filtered through Whatman filter paper (Millipore Corporation, Maid Stone, UK). This solution (50 ml) was passed through IAC at flow-rate of 1-2 drops s-1. The column was washed with $20 \mathrm{ml}$ of PBS (1-2 drops s-1). Elution was performed with $3 \mathrm{ml}$ of methanol and acetic acid 98/2 v/v. The elute was evaporated to dryness under nitrogen stream. The residue was re-dissolved in $250 \mu \mathrm{l}$ of HPLC mobile phase and injected into HPLC system. For samples of powdered milk $5 \mathrm{~g}$ were suspended in $30 \mathrm{ml}$ of distilled water, heated to $50^{\circ} \mathrm{C}$, homogenized and then processed as for liquid milk.

AFM1. Milk samples were previously skimmed by means of addition of Celite and centrifugation at $3000 \mathrm{rpm}$ for $10 \mathrm{~min}$. After elimination of the fat layer, $50 \mathrm{ml}$ of milk was filtered through Whatman filter paper (Millipore Corporation, Maid Stone, UK) and then passed through IAC at flow-rate of 1-2 drops s${ }^{-1}$. The column was washed with $20 \mathrm{ml}$ of PBS (1-2 drops $\mathrm{s}^{-1}$ ). Elution was performed with $3 \mathrm{ml}$ of methanol. The elute was evaporated to dryness under stream of nitrogen. The residue was re-dissolved in $250 \mu$ l of HPLC mobile phase and injected into the HPLC system. For samples of powdered milk $5 \mathrm{~g}$ were suspended in $30 \mathrm{ml}$ of distilled water, heated to $50^{\circ} \mathrm{C}$, homogenized and then processed as for liquid milk.

Spiked samples. Samples spiked before extraction were used to check the performance of the extraction and clean-up procedure and to obtain validation parameters. Spiking solutions of mycotoxins were prepared daily by dilution with HPLC mobile phases. For samples of liquid 
milk, after thoroughly mixing for $30 \mathrm{~min}$, the mycotoxins fortified milks were left for at least 2 hours at room temperature to enable equilibration and used to assay the cleaning procedures prior to HPLC analysis. For samples of powdered milk, spiked samples were prepared by adding appropriate volume of the spiking solution of mycotoxins to the milk suspension (described above) and then processed as for liquid milk.

\section{High-performance liquid chromatography}

The chromatographic system consisted of Jasco880 pump and Jasco821 fluorescence detector (Jasco, Tokyo, Japan). JascoBorwin software was used for data processing. The excitation wavelength $(\lambda \mathrm{ex})$ and emission wavelength $(\lambda \mathrm{em})$ were set at 380 and $420 \mathrm{~nm}$ for OTA and at 365 and $435 \mathrm{~nm}$ for AFM1, respectively. The reversed-phase column was a Luna C18 ODS2, $3 \mu \mathrm{m},(4.6 \mathrm{x} 150 \mathrm{~mm})$ (Phenomenex® Torrance, CA, USA). The column was kept at room temperature. The HPLC was operated with mobile phase system consisting of methanolphosphate buffer solution pH 7.5 (0.03 M Na2HPO4, 0.007M NaH2PO4) 50/50 \% v/v at flow rate of $1 \mathrm{ml} / \mathrm{min}$ and acetonitrile-water $23 / 77 \% \mathrm{v} / \mathrm{v}$ at flow rate of $1 \mathrm{ml} / \mathrm{min}$, for OTA and AFM1, respectively. Calibration curves were based on the analysis of triplicate standards solution at 5 concentration levels in matrix and resulted in good linear relationship between peak area and mycotoxins concentration $\left(\mathrm{R}^{2}>0.999\right)$. The limits of detection (LOD) and quantitation (LOQ), calculated as threefold and tenfold the standard deviation of the intercepts of calibration curves are reported in table 1 . The recovery (percentage of standard added to sample that is recovered after extraction and clean-up) of the extraction method was determined by sample fortification (Table 2). Intra-day reproducibility was evaluated by analyzing three milk samples with mycotoxins to obtain three different concentrations $(10,50$, and $100 \mathrm{ng} / \mathrm{L}$ ). Day-to-day reproducibility was determined by analysis of three replicate samples of the three concentrations $(10,50$, and $100 \mathrm{ng} / \mathrm{L})$ on seven consecutive days. From the data obtained, intra- and interday coefficient of deviations (CV) were calculated. 


\section{RESULTS AND DISCUSSION}

A total of 185 infant cow's milk-based formula samples were analyzed. AFM1 was detected only in 2 samples (range 11.8-15.3 ng/L) from the same brand (n. = 10). The AFM1 contamination levels and incidence in infant formula marketed in Italy were lower than those observed in previous studies regarding milk analysis (Galvano et al., 1998; 2001). These results are probably due to the increased attention paid in European countries to the presence of aflatoxins in feeds and milk products and suggest that regulatory limits appear to be helpful.

OTA was detected in $133(72 \%)$ samples (range 35.1-689.5 ng/L). The most contaminated one was a pre-term ready-to-use preparation containing $689.5 \mathrm{ng} / \mathrm{L}$ of OTA. In contrast to AFM1, no regulation for OTA in milk exists, even though it has been suggested that the level of this toxin in cow's milk may exceed the TDI of $5 \mathrm{ng} / \mathrm{kg} \mathrm{b}$.w. per day for small children in some areas in Norway. The European legislation limit of $0.50 \mathrm{ppb}(\mu \mathrm{g} / \mathrm{L})$ for 
cereal-based infant foods was established (EC, 2006). Regarding OTA, Valenta and Goll (1996) did not find OTA in any of the 121 cow's milk samples analyzed from a northern region of Germany, while OTA was present in a small percentage (10-15\%) of milk samples in Sweden and Norway in the range of 10-50 ng/L (Skaug, 1999; Breitholtz-Emanuelsson et al., 1993). The reason of our data could be a higher contamination of feedstuffs in Italy or the existence of other possible routes of OTA exposure such as inhalation of airborne particles containing mycotoxins, as suggested by Skaug (1999). Furthermore, there can be other possible sources of OTA in samples other than the original milk used for manufacturing infant formulas. Different ingredients have been added to infant formulae not only to simulate better the composition of breast milk, but also to impart health benefits. Raw material (cow's milk or isolated protein), processing methods, additives or mineral supplements, and storage will in part determine the levels of minor and trace constituents present in the final product. In the present study, correlations analysis between the OTA contamination levels of different types of infant formula and their main characteristics (lipid, protein and carbohydrates contents) showed no significant $(p>0.05)$ correlation between parameters.

It has been observed that OTA contamination was $80 \%$ in the ready-to-use preparations and $63 \%$ in the powdered samples. Pre-term and starter ready-to-use formula preparations showed the same incidence of positive samples $(80 \%)$, while pre-term powdered formula showed $100 \%$ incidence and starter formula the $60 \%$, although the numbers of pre-term powdered formula tested were insufficient to obtain an accurate picture of the incidence contamination (Table 4).

Non-parametric statistical analyses (Mann Whitney test) were performed with OTA content for comparison of the different types of formulas, not establishing significant differences $(p>0.05)$ between different groups. The OTA content in both powder and readyto-use formulas has been statistically evaluated to understand the influence of the aggregation 
state on final OTA level in formulas studied. OTA concentration found in 9 different formulas marked in both forms did not differ significantly, indicating that the most important factor of OTA levels was the formula ingredients. Furthermore, the present study shows a tendency for pre-term both powder and ready-to-use formula to have only slightly higher OTA levels than starter formulas.

Bar diagrams of OTA concentration distribution for all formulas commercialized by each brand analyzed $(\mathrm{n} .=14)$ are shown in figures 3-4. A comparison of significant differences (ANOVA, $p=0.0182$ ) among ready-to-use preparations provided from the commercial brands was performed (Figure 3). Among the ready-to-use preparations, OTA level provided by brand $1(\mathrm{n} .=15,216.8 \pm 217.4 \mathrm{ng} / \mathrm{L}$, range 54.9-689.5 ng/L) was significantly higher (Tukey test, $p<0.05$ ) than those from most of the other brands. Regarding the powdered formulas, a comparison of significant differences (ANOVA, $\mathrm{p}=0.0438$ ) among commercial brands was performed (Figure 4). OTA level provided by brand 1 (n. $=5$, 195.2 $\pm 138.2 \mathrm{ng} / \mathrm{L}$, range 65.4-340.5 ng/L) was significantly higher (Tukey test, $p<0.05$ ) than those from most of the other brands.

Non-parametric statistical analyses (Mann Whitney test) were performed with OTA content for comparison of the different types of formulas provided from the same commercial brand (pre-term $v s$. starter formula), not establishing significant differences $(\mathrm{p}>0.05)$ between different groups. The same statistical analyses were performed with OTA content for comparison of the different types of formulas provided from the same commercial brand (powdered vs. ready-to-use formula), not establishing significant differences $(p>0.05)$ between different groups.

The OTA concentrations determined in the different types of formulas were used to calculate mean daily and weekly dietary OTA intakes by infants on the basis of feeding tables provided by brands, under the assumption that they receive only formulas. The mean daily 
intakes for ready-to-use pre-term and starter formula were $16.08 \pm 3.93$ and $12.29 \pm 2.12 \mathrm{ng} / \mathrm{kg}$ b.w., respectively; while corresponding weekly intakes were $112.56 \pm 27.51$ and $86.03 \pm 14.84$ ng/kg b.w., respectively. The mean daily and weekly intakes for powdered starter formula were $10.67 \pm 1.95$ and $74.69 \pm 13.65 \mathrm{ng} / \mathrm{kg}$ b.w., respectively; while for powdered pre-term formula it has been impossible to calculate these values because of the few samples.

The Scientific Committee for Food (SCF) reviewed the toxicology on OTA and concluded that it would be prudent to reduce exposure to OTA ensuring that exposures are towards the lower end of the range of tolerable daily intakes of $1.2-14 \mathrm{ng} / \mathrm{kg} \mathrm{b.w.} \mathrm{per} \mathrm{day.}$ OTA was also evaluated by the Joint FAO/WHO Expert Committee on Food Additives (JECFA) and a provisional tolerable weekly intake (PTWI) of $100 \mathrm{ng} / \mathrm{kg}$ b.w. was established. In the present investigation, the average OTA levels in pre-term ready-to-use infant formula were sufficient to cause a higher intake of OTA than the suggested TDI and PTWI, while other formulations were below these limits.

Interestingly, OTA was also detected in milk from healthy mothers in Germany, Norway, Sweden, Hungary, Italy, Australia and Sierra Leone (Scott, 2005). The present results are comparable with those obtained by Turconi et al. (2004) and Galvano et al. (2008) in two studies regarding human milk performed in Italy (198 of 231 samples contaminated with $1-57 \mathrm{ng} / \mathrm{L}$ and 74 of 82 samples contaminated with $<5 \mathrm{ng} / \mathrm{L}-405 \mathrm{ng} / \mathrm{L}$, respectively), while are lower than those reported by Micco et al. (1991; 1995) (ranges 1700-6600 ng/L and $100-12000 \mathrm{ng} / \mathrm{L}$, respectively).

Due to high toxicity and carcinogenic properties of OTA, its presence in milk is a concern. OTA is resistant to thermal inactivation and other varieties of food processing procedures, so to produce high quality milk, it is essential to keep feeds free from contamination by OTA. Mycotoxin concentrations in animal feed can be reduced by good manufacturing practice and good storage practices. On the other hand, infant formula 


\section{REFERENCES}

Anderson PK, Cunningham AA, Patel NG, Morales FJ, Epstein PR, Daszak P. 2004. Emerging infectious diseases of plants: Pathogen pollution, climate change and agriculture drivers. Trends in Ecology \& Evolution 19: 536-544.

Beretta B, De Domenico R, Gaiaschi A, Ballabio C, Galli CL, Gigliotti C, Restani P. 2002. Ochratoxin A in cereal-based baby foods: occurrence and safety evaluation. Food Additives and Contaminants 19: 70-75.

Breitholtz-Emanuelsson A, Olsen M, Oskarsson A, Palminger I, Hult K. 1993. Ochratoxin A in cow's milk and in human milk with corresponding human blood samples. The Journal of AOAC International 76: 842-846.

Ceovic S, Hrabar A, Saric M. 1992. Epidemiology of Balkan endemic nephropathy. Food and Chemical Toxicology 30: 183-188. 
EC. 2003a. Commission Regulation (EC) No 2174/2003 of 12 December 2003 amending Regulation (EC) No 466/2001 as regards aflatoxins. Official Journal of the European Union L326: 12.

EC. 2003b. Commission Directive 2003/100/EC of 31 October 2003 amending Annex I to Directive 2002/32/EC of the European Parliament and of the Council on undesirable substances in animal feed. Official Journal of the European Union L285: 33.

EC. 2006. Commission Regulation (EC) No 1881/2006 of 19 December 2006 setting maximum levels for certain contaminants in foodstuffs. Official Journal of the European Union L364: 5.

EFSA, 2006. Opinion of the scientific panel on contaminants in the food chain on a request from the commission related to ochratoxin a in food. The EFSA Journal 365: 1-56.

EFSA. 2004. Opinion of the scientific panel on contaminants in the food chain on a request from the commission related to aflatoxin B1 as undesirable substance in animal feed. The EFSA Journal 39: 1-27.

FAO/WHO, 2001. Ochratoxin A. In: Safety evaluation of certain mycotoxins in food, Prepared by the 56th Meeting of the Joint FAO/WHO Expert Committee on Food Additives (JECFA). WHO Food Additives Series 47, pp 281-387. World Health Organisation, Geneva, Switzerland.

Galvano F, Galofaro V, de Angelis A, Galvano M, Bognanno M, Galvano G. 1998. Survey of the occurrence of aflatoxin M1 in dairy products marketed in Italy. Journal of Food Protection 61: $738-741$.

Galvano F, Galofaro V, Ritieni A, Bognanno M, De Angelis A, Galvano G. 2001. Survey of the occurrence of aflatoxin M1 in dairy products marketed in Italy: second year of observation. Food Additives and Contaminants 18: 644-646. 
Galvano F, Pietri A, Bertuzzi T, Gagliardi L, Ciotti S, Luisi S, Bognanno M, La Fauci L, Iacopino AM, Nigro F, Li Volti G, Vanella L, Giammanco G, Tina GL, Gazzolo D. 2008. Maternal dietary habits and mycotoxin occurrence in human mature milk. Molecular and Nutritional Food Research 52: 496-501.

Hult K, Teiling A, Gatenbeck S. 1976. Degradation of ochratoxin A by a ruminant. Applied and Environmental Microbiology 32: 443-444.

IARC. 1993a. Aflatoxins. Some naturally occurring substances: food items and constituents, heterocyclic aromatic amines and mycotoxins. IARC Monographs on the Evaluation of Carcinogenic Risks to Humans, vol. 56, Lyon, France, pp. 245-395.

IARC. 1993b. Ochratoxin A. Some naturally occurring substances; food items and constituents, heterocyclic aromatic amines and mycotoxins, IARC Monographs on the Evaluation of Carcinogenic Risks to Humans, vol. 56, Lyon, France, pp. 489-521.

Krogh P. 1987. Mycotoxins in Food. Food Science and Technology. New-York, NY, USA: Academic Press. Ochratoxins in food; p. 97-121.

Krogh P. 1992. Role of ochratoxin in disease causation. Food and Chemical Toxicology 30: 213-224.

Lombaert GA, Pellaers P, Roscoe V, Mankotia M, Neil R, Scott PM. 2003. Mycotoxins in infant cereal foods from the Canadian retail market. Food Additives and Contaminants 20: 494-504.

Micco C, Ambruzzi MA, Miraglia M, Brera C, Onori R, Benelli L. 1991. Contamination of human milk with ochratoxin A. IARC scientific publications 115: 105-108.

Micco C, Miraglia M, Brera C, Corneli S, Ambruzzi A. 1995. Evaluation of ochratoxin A in human milk in Italy. Food Additives and Contaminants 12: 351-354. 
SCF. 1998. Opinion on of the Scientific Committee on Food (SCF) on ochratoxin A. $\begin{array}{lllll}\text { Expressed } & \text { on } & 17 & \text { September } & \text { Available }\end{array}$ http://europa.eu.int/comm/food/fs/sc/scf/out14_en.html Accessed November 15, 2008.

Scott PM. 2005. Biomarkers of human exposure to ochratoxin A. Food Additives and Contaminants 22: 99-107.

Skaug MA. 1999. Analysis of Norwegian milk and infant formulas for ochratoxin A. Food Additives and Contaminants 16: 75-78.

Sreemannarayana O, Frohlich AA, Vitti TG, Marquardt RR, Abramson D. 1988. Studies of the tolerance and disposition of ochratoxin A in young calves. Animal Science 66: 17031711.

Tam J, Mankotia M, Mably M, Pantazopoulos P, Neil RJ, Calway P, Scott PM. 2006. Survey of breakfast and infant cereals for aflatoxins B1, B2, G1 and G2. Food Additives and Contaminants 23: 693-699.

Turconi G, Guarcello M, Livieri C, Comizzoli S, Maccarini L, Castellazzi AM, Pietri A, Piva G, Roggi C. 2004. Evaluation of xenobiotics in human milk and ingestion by the newborn--an epidemiological survey in Lombardy (Northern Italy). European Journal of Nutrition 43: 191197.

Valenta H, Goll M. 1996. Determination of ochratoxin A in regional samples of cow's milk from Germany. Food Additives and Contaminants 13: 669-676.

Valenta H. 1998. Chromathographic methods for the determination of ochratoxin A in animal and human tissues and fluids. Journal of Chromathography A 815: 75-92. 


\section{FIGURE LEGENDS}

Figure 1. Chromatograms obtained from extracts of (a) a blank milk sample and (b) a milk sample spiked with AFM1.

Figure 2. Chromatograms obtained from extracts of (a) a blank milk sample and (b) a milk sample spiked with OTA.

Figure 3. OTA levels (ng/L) in the ready-to-use milk-based infant formulas provided by different manufacturers.

Figure 4. OTA levels (ng/L) in the powdered milk-based infant formulas provided by different manufacturers. 


\begin{tabular}{|c|c|c|c|c|c|}
\hline Brand & Type & Lipids & Proteins & Carbohydrates & Minerals \\
\hline 5 & Pre-term & 3.75 & 2.03 & 8.32 & 0.37 \\
\hline 1 & Pre-term & 4.80 & 3.20 & 10.90 & 0.50 \\
\hline 1 & Pre-term & 3.80 & 2.20 & 10.10 & 0.40 \\
\hline 2 & Pre-term & 4.40 & 2.40 & $\mathbf{7 . 7 0}$ & 0.34 \\
\hline 3 & Pre-term & 4.20 & 2.30 & 8.60 & 0.47 \\
\hline 4 & Pre-term & 4.20 & 2.20 & 8.30 & 0.36 \\
\hline 4 & Pre-term & 4.00 & 2.00 & 7.80 & 0.35 \\
\hline 6 & Pre-term & 4.00 & 2.00 & 7.80 & 0.35 \\
\hline 6 & Pre-term & 4.00 & 2.30 & 7.50 & 0.32 \\
\hline 7 & Pre-term & 4.40 & 2.30 & 8.30 & 0.400 \\
\hline 2 & Starter & 3.60 & 1.40 & 7.40 & 0.22 \\
\hline 4 & Starter & 4.10 & 1.40 & 7.30 & 0.30 \\
\hline 6 & Starter & 3.70 & 1.40 & 7.50 & 0.25 \\
\hline 3 & Starter & 3.60 & 1.20 & 7.50 & 0.25 \\
\hline 8 & Starter & 3.60 & 1.40 & 7.70 & 0.30 \\
\hline 9 & Starter & 3.60 & 1.30 & 7.70 & 0.30 \\
\hline 4 & Starter & 3.50 & 1.70 & 7.20 & 0.22 \\
\hline 5 & Starter & 3.50 & 1.50 & 8.30 & 0.32 \\
\hline 1 & Starter & 3.10 & 1.80 & 8.30 & 0.30 \\
\hline 7 & Starter & 3.70 & 1.30 & 7.70 & 0.30 \\
\hline
\end{tabular}

Table 1. Composition of liquid (ready-to-use) infant formula analyzed, (values are expressed as g/100 $\mathrm{ml}$ of product). 


\begin{tabular}{|c|c|c|c|c|c|c|}
\hline Brand & Type & & Lipids & Proteins & Carbohydrates & Minerals \\
\hline \multirow[t]{2}{*}{2} & \multirow[t]{2}{*}{ Pre-term } & $100 \mathrm{~g}$ of powd. & $\mathbf{0}$ & 7.60 & 71.5 & $\mathbf{3 . 3 0}$ \\
\hline & & $4.2 \% / 100 \mathrm{ml}$ & $\mathbf{0}$ & 0.30 & 3.00 & 0.14 \\
\hline \multirow[t]{2}{*}{1} & \multirow[t]{2}{*}{ Starter } & $100 \mathrm{~g}$ of powd. & 22.3 & 12.9 & 59.6 & 2.20 \\
\hline & & $13.9 \% / 100 \mathrm{ml}$ & 3.10 & 1.80 & 8.30 & 0.30 \\
\hline \multirow[t]{2}{*}{10} & \multirow[t]{2}{*}{ Starter } & $100 \mathrm{~g}$ of powd. & 26.5 & 11.2 & 57.3 & 1.90 \\
\hline & & $13.5 \% / 100 \mathrm{ml}$ & 3.60 & 1.50 & 7.70 & 0.27 \\
\hline \multirow[t]{2}{*}{11} & \multirow[t]{2}{*}{ Starter } & $100 \mathrm{~g}$ of powd. & 25.9 & 10.4 & 55.5 & 1.50 \\
\hline & & $13.5 \% / 100 \mathrm{ml}$ & 3.50 & 1.40 & 7.50 & 0.20 \\
\hline \multirow[t]{2}{*}{12} & \multirow[t]{2}{*}{ Starter } & $100 \mathrm{~g}$ of powd. & 28.1 & 13.6 & 53.3 & 2.00 \\
\hline & & $12.9 \% / 100 \mathrm{ml}$ & 3.60 & 1.70 & 6.90 & 0.25 \\
\hline \multirow[t]{2}{*}{13} & \multirow[t]{2}{*}{ Starter } & $100 \mathrm{~g}$ of powd. & 23.6 & 11.0 & 60.3 & 1.90 \\
\hline & & $13.5 \% / 100 \mathrm{ml}$ & 3.30 & 1.50 & 8.40 & 0.27 \\
\hline \multirow[t]{2}{*}{14} & \multirow[t]{2}{*}{ Starter } & $100 \mathrm{~g}$ of powd. & 25.9 & 12.5 & 57.1 & 1.80 \\
\hline & & $13.5 \% / 100 \mathrm{ml}$ & 3.50 & 1.70 & 7.70 & 0.22 \\
\hline \multirow[t]{2}{*}{2} & \multirow[t]{2}{*}{ Starter } & $100 \mathrm{~g}$ of powd. & 25.6 & 10.2 & 52.9 & 1.60 \\
\hline & & $13.9 \% / 100 \mathrm{ml}$ & 3.60 & 1.40 & 7.30 & 0.22 \\
\hline \multirow[t]{2}{*}{9} & \multirow[t]{2}{*}{ Starter } & $100 \mathrm{~g}$ of powd. & 26.7 & 9.60 & 57 & 2.20 \\
\hline & & $13.5 \% / 100 \mathrm{ml}$ & 3.60 & 1.30 & 7.70 & 0.30 \\
\hline \multirow[t]{2}{*}{4} & \multirow[t]{2}{*}{ Starter } & $100 \mathrm{~g}$ of powd. & 25.9 & 12.5 & 53.0 & 1.55 \\
\hline & & $13.5 \% / 100 \mathrm{ml}$ & 3.50 & 1.70 & 7.20 & 0.21 \\
\hline \multirow[t]{2}{*}{8} & \multirow[t]{2}{*}{ Starter } & $100 \mathrm{~g}$ of powd. & 26.7 & 10.4 & 57.0 & 2.20 \\
\hline & & $13.5 \% / 100 \mathrm{ml}$ & 3.60 & 1.40 & 7.70 & 0.30 \\
\hline \multirow[t]{2}{*}{7} & \multirow[t]{2}{*}{ Starter } & $100 \mathrm{~g}$ of powd. & 27.5 & 9.60 & 57.0 & 2.20 \\
\hline & & $13.5 \% / 100 \mathrm{ml}$ & 3.70 & 1.30 & 7.70 & 0.30 \\
\hline \multirow[t]{2}{*}{5} & \multirow[t]{2}{*}{ Starter } & $100 \mathrm{~g}$ of powd. & 24.8 & 10.8 & 59.60 & 2.30 \\
\hline & & $14 \% / 100 \mathrm{ml}$ & 3.47 & 1.51 & 8.34 & 0.32 \\
\hline \multirow[t]{2}{*}{7} & \multirow[t]{2}{*}{ Starter } & $100 \mathrm{~g}$ of powd. & 27.5 & 9.60 & 57.2 & 2.20 \\
\hline & & $13.5 \% / 100 \mathrm{ml}$ & 3.70 & 1.30 & 7.70 & 0.30 \\
\hline 2 & Starter & $100 \mathrm{~g}$ of powd. & 25.6 & 12.8 & 56.5 & 2.20 \\
\hline & & $13.3 \% / 100 \mathrm{ml}$ & 3.40 & 1.70 & 7.50 & 0.30 \\
\hline 5 & Starter & $100 \mathrm{~g}$ of powd. & 23.0 & 12.50 & 59.0 & 3.00 \\
\hline & & $14 \% / 100 \mathrm{ml}$ & 3.22 & 1.75 & 8.26 & 0.42 \\
\hline 3 & Starter & $100 \mathrm{~g}$ of powd. & 27.7 & 9.50 & 57.9 & 1.90 \\
\hline & & $12.9 \% / 100 \mathrm{ml}$ & 3.60 & 1.20 & 7.50 & 0.24 \\
\hline
\end{tabular}

Table 2. Composition of powder infant formula analyzed. 


\begin{tabular}{|c|c|c|c|c|c|}
\hline \multicolumn{6}{|c|}{ AFM1 } \\
\hline Matrix & LOD & LOQ & Recovery \% $\%$ SD & CV\% intra-day & CV\% inter-day \\
\hline Liquid & \multirow{2}{*}{$2.5 \mathrm{ng} / \mathrm{L}$} & \multirow{2}{*}{5 ng/L } & $75.0 \pm 0.3 \%$ & 3 & 8 \\
\hline Powders & & & $69.5 \pm 0.2 \%$ & 7 & 9 \\
\hline \multicolumn{6}{|c|}{$\mathbf{O A}$} \\
\hline Matrix & LOD & LOQ & Recovery \% \pm SD & CV\% intra-day & CV\% inter-day \\
\hline Liquid & \multirow{2}{*}{$1.25 \mathrm{ng} / \mathrm{L}$} & \multirow{2}{*}{$6.25 \mathrm{ng} / \mathrm{L}$} & $87.1 \pm 0.3 \%$ & 2 & 7 \\
\hline Powders & & & $79.5 \pm 0.5 \%$ & 3 & 8 \\
\hline
\end{tabular}

Table 3. Validation parameters for HPLC methods of AFM1 and OA, (LOD, limit of detection; LOQ, limit of quantitation; SD, standard deviation; CV, coefficient of variation). 


\begin{tabular}{|c|c|c|c|c|}
\hline Infant formula & Number of samples & Numbers of positives (\%) & Mean \pm SE & Range \\
\hline $\begin{array}{l}\text { Pre-term } \\
\text { Liquid } \\
\text { Powder }\end{array}$ & $\begin{array}{c}55 \\
50 \\
5 \\
\end{array}$ & $\begin{array}{l}45(80 \%) \\
40(80 \%) \\
5(100 \%) \\
\end{array}$ & $\begin{array}{l}106.2 \pm 23.88 \mathrm{ng} / \mathrm{L} \\
107.2 \pm 26.26 \mathrm{ng} / \mathrm{L} \\
96.10 \pm 15.59 \mathrm{ng} / \mathrm{L}\end{array}$ & $\begin{array}{l}<\text { LOD-689.5 ng/L } \\
<\text { LOD-689.5 ng/L } \\
80.49-127.3 \mathrm{ng} / \mathrm{L}\end{array}$ \\
\hline $\begin{array}{l}\text { Starter } \\
\text { Liquid } \\
\text { Powder }\end{array}$ & $\begin{array}{l}130 \\
50 \\
80\end{array}$ & $\begin{array}{l}88(68 \%) \\
40(80 \%) \\
48(60 \%)\end{array}$ & $\begin{array}{l}69.77 \pm 8.81 \mathrm{ng} / \mathrm{L} \\
65.57 \pm 11.33 \mathrm{ng} / \mathrm{L} \\
72.40 \pm 12.52 \mathrm{ng} / \mathrm{L}\end{array}$ & $\begin{array}{l}<\text { LOD-355.8 ng/L } \\
<\text { LOD-299.1 ng/L } \\
<\text { LOD-355.8 ng/L }\end{array}$ \\
\hline & 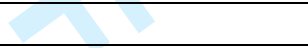 & & & \\
\hline
\end{tabular}

Table 4. OA concentrations in different types of infant formulas investigated, (SE, standard error of the mean; LOD, limit of detection). 
Figure Legends

Figure 1. Chromatograms obtained from extracts of (a) a blank milk sample and (b) a milk sample spiked with AFM1.

Figure 2. Chromatograms obtained from extracts of (a) a blank milk sample and (b) a milk sample spiked with OTA.

Figure 3. OTA levels (ng/L) in the ready-to-use milk-based infant formulas provided by different manufacturers.

Figure 4. OTA levels (ng/L) in the powdered milk-based infant formulas provided by different manufacturers. 
(a)
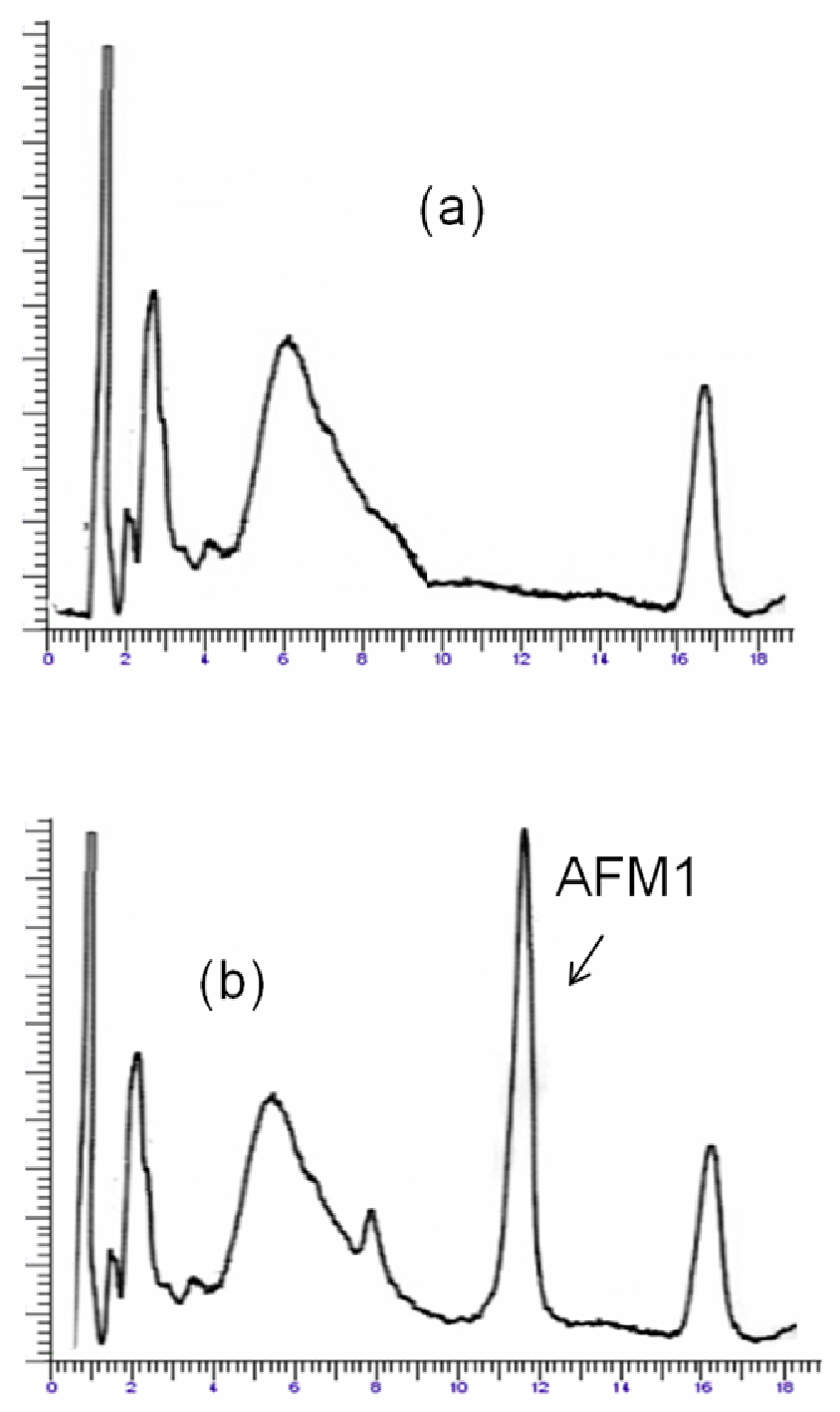

\section{Figure 1}

http://mc.manuscriptcentral.com/tfac Email: fac@tandf.co.uk 

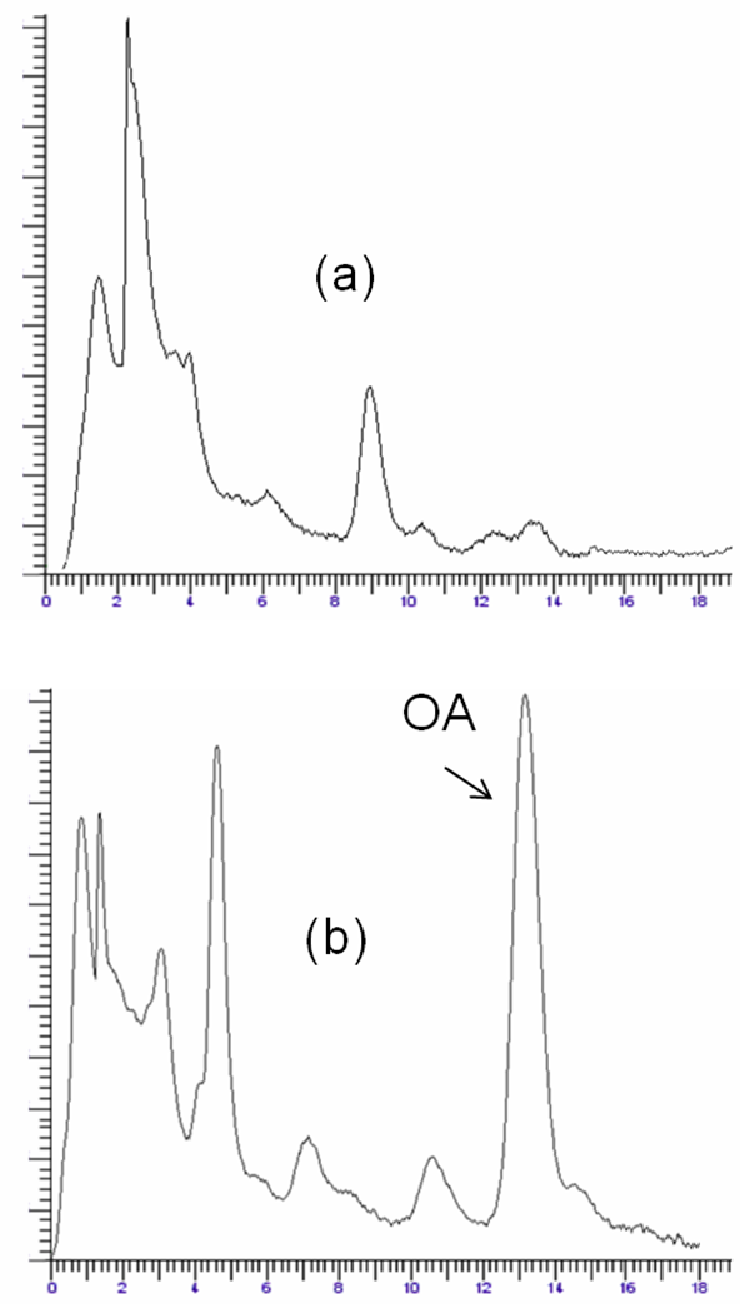

\section{Figure 2}

http://mc.manuscriptcentral.com/tfac Email: fac@tandf.co.uk 


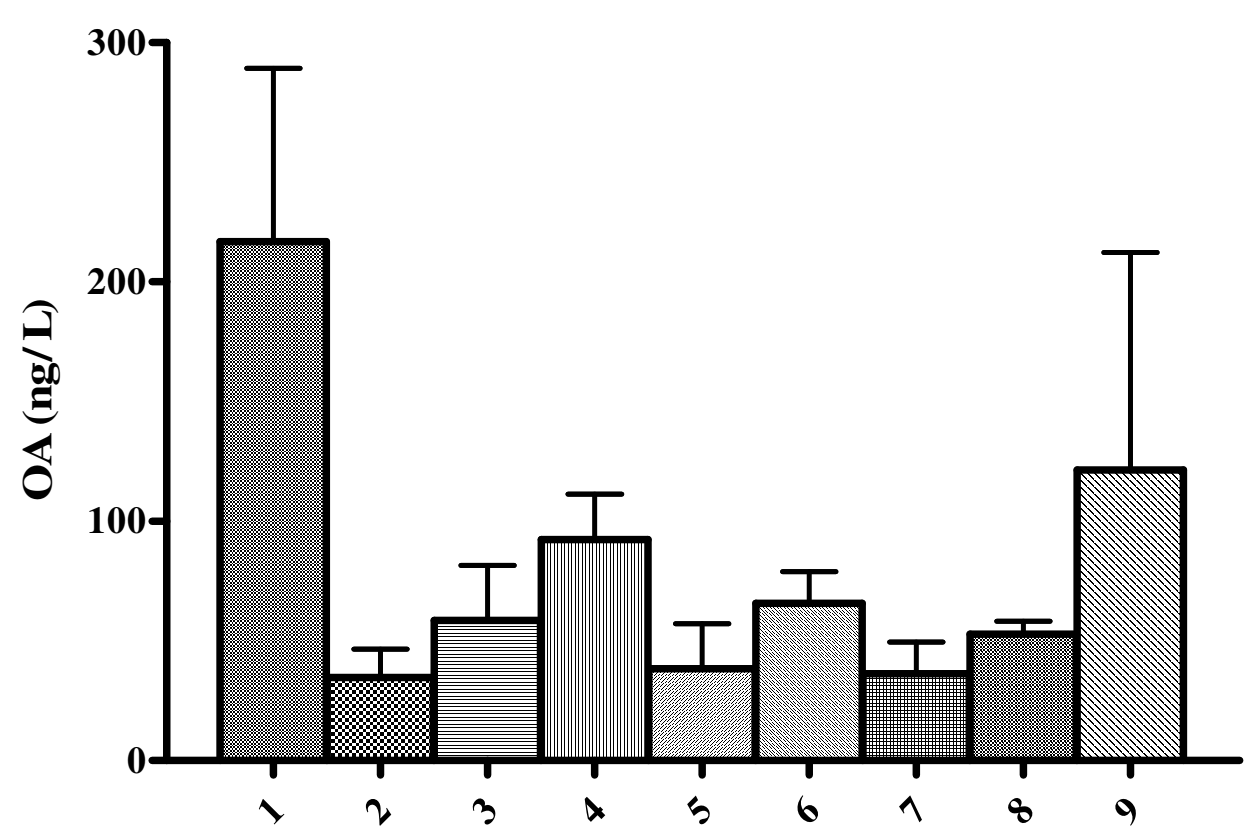

Figure 3 


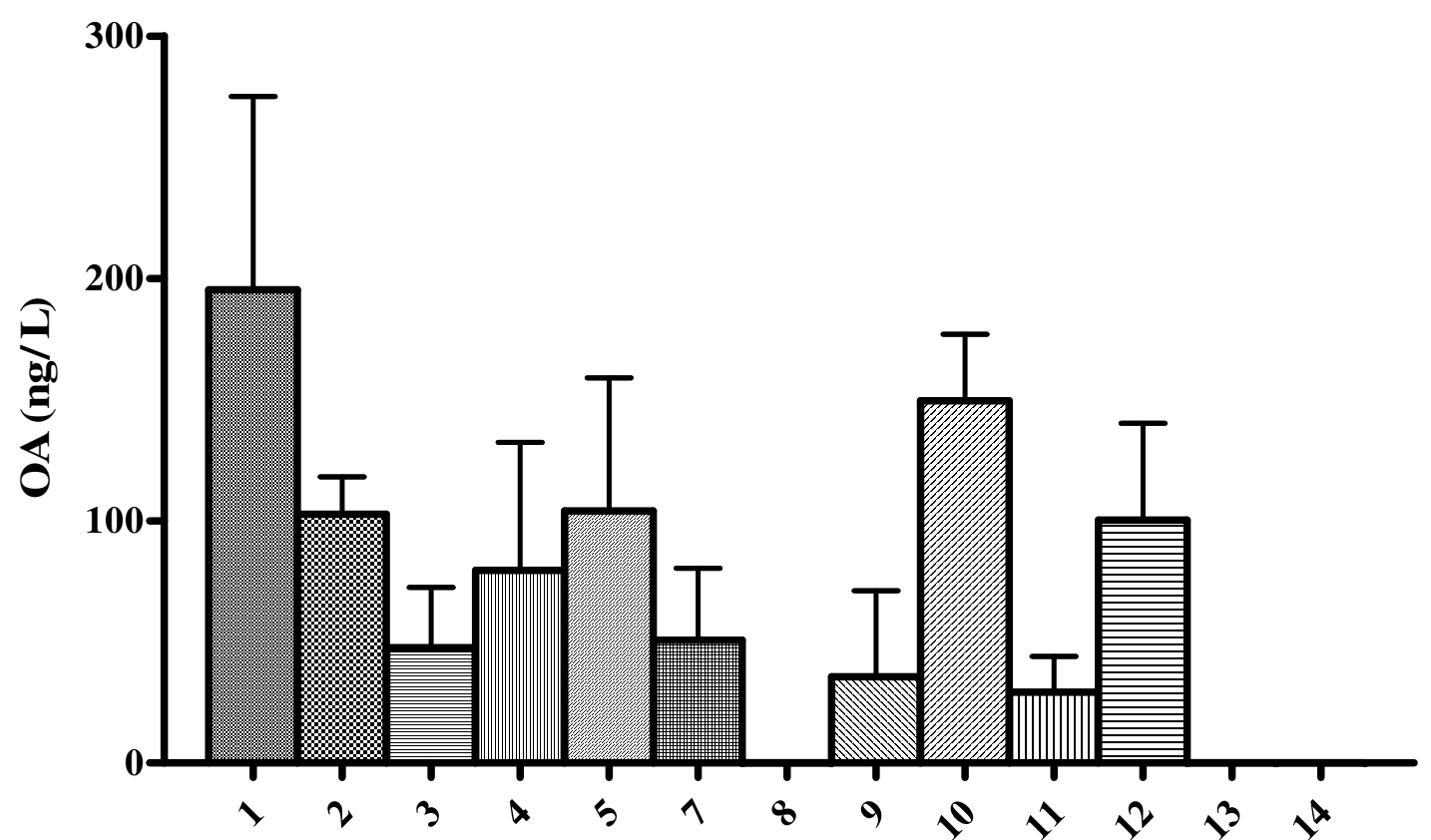

Figure 4 